\title{
Digital portfolio og peer to peer feedback - skaber transfer og engagerede studerende
}

\section{Ditte Jacobsen}

Lektor, cand. scient., Master Naturfagsdidaktik Bioanalytikeruddannelsen, Professionshøjskolen Metropol.

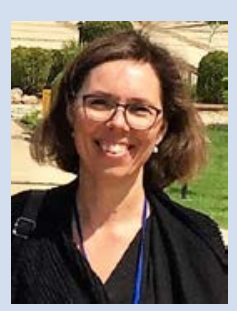

Jesper Bahrenscheer Lektor, cand. scient., Bioanalytikeruddannelsen, Professionshøjskolen Metropol.

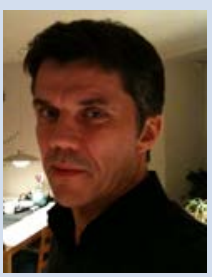




\section{Abstract (dansk)}

På Bioanalytikeruddannelsen på Professionshøjskolen Metropol har vi på tiugers modulet "Molekylærbiologiske og genetiske analyser", udviklet en digital portfolio som didaktisk redskab. Portfolien er blevet afprøvet på fire forløb, og har været med til at skabe større engagement blandt de studerende og øget transfer mellem teori og praksis. Artiklen tager afsæt i erfaringerne fra udvikling, anvendelse og evaluering af den digitale portfolio og peer to peer feedback.

Portfolien er digital og tilknyttet Metropols Learning Management System. De studerende uploader individuelt ugentligt deres arbejde tilknyttet ugens fokusområde. En gang om ugen giver de studerende hinanden peerfeedback på ugens arbejde.

Anvendelsen af portfolien har øget de studerendes kompetencer til at give og anvende peerfeedback. De studerende angiver, at de opnår en høj grad af læring i forbindelse med arbejdet med portfolien, bl.a. fordi de oplever, at det forpligter, at de skal dele portfolien og feedbacken med en medstuderende. Desuden oplever vi som undervisere, at de studerendes faglige niveau er blevet væsentligt forøget blandt de studerende, der aktivt har benyttet portfolien i samspil med feedback.

\section{Abstract (engelsk)}

\section{Digital portfolio and peer to peer feedback creates transfer and student engagement}

At the Biomedical Laboratory Science Programme, Metropolitan University College we have developed a digital portfolio. The portfolio was introduced in autumn 2015 at the ten week course "Molecular Biology and Genetic Analysis". The knowledge and experience gained from the development, implementation and evaluation of the use of the digital portfolio and peer to peer feedback will be discussed in this paper.

The digital portfolio is an integrated part of the Learning Management System at Metropolitan University College. Every week the students upload their written work, connected to the theme of the week, and they give each other peer to peer feedback on the work presented in their digital portfolios.

Use of the digital portfolio has enhanced the students' competences to give and make use of peer feedback. The students state that they achieve a high level of learning when working with the portfolio. One reason for this is that they feel committed to do their best because they have to share the portfolio with a peer. As teachers, it is our experience that the depth of learning among 
the students who have actively worked with the digital portfolios and feedback has increased.

\section{Introduktion og baggrund}

Formålet med denne artikel er at diskutere anvendelsesmuligheder, opmærksomhedsfelter og udviklingspotentiale for brug af digital portfolio kombineret med peer to peer fedback inden for undervisningen på de videregående uddannelser.

Baggrunden for indførelsen af portfolio på Bioanalytikeruddannelsen Metropol var et ønske om mere skriftlighed, muligheden for dybere læring samt bedre transfer (Nielsen \& Månsson, 2011) mellem det praktiske laboratoriearbejde og den teoretiske del af undervisningsforløbet. Portfolien blev indført i efteråret 2015 på det ti uger lange undervisningsforløb "Molekylærbiologiske og genetiske analyser", modul 9 (M09). Modulet har en stærk praksistilknytning, da praksiselementerne på modulet er udarbejdet $\mathrm{i}$ tæt samarbejde med fagpersoner fra hospitalslaboratorier. I løbet af modulet skal de studerende opbygge en dyb forståelse for molekylærbiologi og molekylærbiologiske analyseprincipper.

Den pædagogiske og didaktiske udfordring var, at de studerendes læring ofte ikke var tilstrækkelig dyb, og de havde vanskeligt ved at anvende viden, færdigheder og kompetencer opnået i laboratoriet i skriftlige besvarelser med tilstrækkeligt detaljeret fagsprog. Der var i modulet tidligere ikke fokus på skriftlighed, men på kolaborativ mundtlig videndeling ved problembaseret læring (PBL) ${ }^{1}$, hvilket gjorde, at der ikke var tilstrækkelig alignment mellem aktiviteter i undervisningen og den skriftlige udprøvning. Dette kan have været en medvirkende årsag til, at $91 \%$ af de studerende i modulevalueringen i foråret 2015, hvilket var før indførelsen af portfolien, har svaret, at de er helt eller delvist enige i udsagnet: "Det vil være godt for min læring at arbejde mere med det skriftlige fagsprog." Desuden svarede kun $6 \%$ af de adspurgte, at de er helt enige i udsagnet: "Jeg er god til at motivere mig til at studere ud over den skemalagte undervisning."

Underviserteamet på modulet vurderede også, at der var mangel på alignment mellem undervisningsaktiviteterne på modulet og udprøvningen, hvilket var en tre timers skriftlig eksamen uden hjælpemidler, mens undervisningen var organiseret som problembaseret læring med mundtlige opsamlinger, laboratorieøvelser, workshops og forelæsninger. Der var i modulets undervisningsaktiviteter således ikke fokus på skriftlighed i forbindelse med

\footnotetext{
1På Bioanalytikeruddannelsen er problembaseret læring (PBL) opbygget over 7-trinsmodellen. Ved et PBL-forløb udarbejder en gruppe på ca. 10 studerende en række læringsmål på baggrund af en situationsbeskrivelse. Ca. en uge senere mødes gruppen igen og diskuterer læringsmålene. Forløbet faciliteres af en PBL-vejleder. For en nærmere redegørelse af PBL på Bioanalytikeruddannelsen på Metropol se Lorenzen og Thomasen, 2017.
} 
anvendelse af teoretisk viden i forhold til planlægning af laboratoriearbejde, resultater opnået i laboratoriet eller fra videnskabelig international litteratur omhandlende forskningsresultater. Biggs og Tang (2007) definerer alignment således:

"The 'alignment' in constructive alignment reflects the fact that the learning activity in the intended outcomes, expressed as a verb, needs to be activated in the teaching if the outcome is to be achieved and in the assessment task to verify that the outcome has in fact been achieved."

(Biggs \& Tang 2007: 52)

For at opnå bedre alignment i undervisningsforløbet og samtidig styrke de studerendes anvendelse af skriftligt fagsprog og transfer mellem praksis og teori valgte vi at indføre portfolioafleveringer.

Et andet argument for at indføre portfolio som en studieaktivitet, var at understøtte dyb læring frem for overfladelæring. Med fokus på de studerendes læringsproces ønskede vi i højere grad at aktivere de studerende og tilrettelægge undervisningen, så de kom mere i dybden med stoffet. Ifølge Biggs og Tang (2007) er en aktiverende undervisning den bedste tilgang til undervisningen, hvis man både har studerende med højt og lavt engagement. Fra evalueringer på Bioanalytikeruddannelsen ved vi, at vi både har meget ambitiøse studerende samt studerende, som primært er interesseret i blot at bestå eksamen. Disse typer af studerende er afbildet i figur 1 som "Academic Susan" og "Non-academic Robert". Ifølge Biggs og Tang (2007) vil studenteraktiverende undervisning medføre, at en større gruppe af de studerende vil være i stand til at forklare, relatere, anvende og teoretisere, end hvis undervisningen udelukkende blev afholdt som underviserstyret envejskommunikation baseret på forelæsningsrækker.

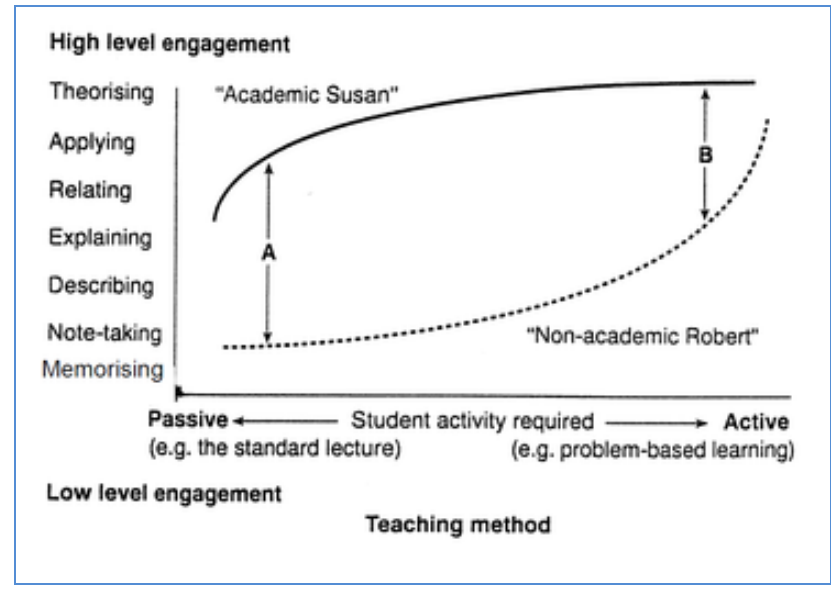

Figur 1. Undervisningsmetoder og studerendes engagement i undervisningen koblet til læring (Biggs \& Tang, 2007, s. 10) 


\section{Artiklens opbygning}

I den første del af artiklen redegøres for begreberne digital portfolio og peer to peer feedback samt hvilke læringsteoretiske og didaktiske begrundelser, der ligger til grund for vores læringsdesign². Dernæst opridses rammerne for modulet "Molekylærbiologiske og genetiske analyser", og hvorledes vi har designet den digitale portfolio og peer to peer feedback. Derefter følger en beskrivelse af undersøgelsesdesignet, hvor vi redegør for og begrunder valg af metoder til dataindsamling. Vi vil i det efterfølgende systematisk redegøre for både kvalitative og kvantitative data, der er indsamlet i de gennemførte undervisningsforløb og ved de efterfølgende evalueringer. Disse erfaringer vil blive diskuteret og perspektiveret i forhold til fremtidigt brug. Vi vil diskutere, hvilken betydning de præsenterede data har for den fremtidige planlægning og udvikling af undervisning på Bioanalytikeruddannelsen på Metropol, og hvorledes de præsenterede ideer kan have betydning for undervisningspraksis generelt på professionshøjskolerne og andre videregående uddannelser. Endelig vil problemstillinger og særlige opmærksomhedsfelter blive diskuteret, og vi vil komme med anbefalinger og perspektiver for yderligere udvikling af den digitale portfolio og peer to peer feedback.

\section{Portfolio som fænomen og kobling til lærerprocesser}

\section{Hvilken portfolio?}

En portfolio er en "mappe", hvor de studerende samler deres arbejde over en længere periode. Den kan rumme forskellige genrer, og arbejdet kan være udført alene eller i samarbejde (Dysthe \& Engelsen, 2005). Dysthe blev i 1993 inspireret til arbejdet med portfolier på baggrund af erfaringer fra USA og Canada (Lund, 2008). Særligt var Dysthe optaget af det dialogiske perspektiv i arbejdet med sproget og dermed en mere konstruktivistisk tilgang til læring i modsætning til datidens fremherskende videnoverførsel, som stadig er normen på mange videregående uddannelser. Ved indførelse af portfolio går man ifølge Dysthe fra monologisk kommunikation og kundskabsoverførsel til dialogisk kommunikation og kundskabskonstruktion (Dysthe \& Engelsen, 2005).

Interessen for at anvende portfolier som pædagogisk redskab i undervisning både i grundskolen, erhvervsskoler, gymnasier og på videregående uddannelser har været stigende, og tilbage i 2008 blev det beskrevet af Lund (2008), hvordan portfolien som pædagogisk redskab kan bidrage til bedre læring.

\footnotetext{
2 For definition af læringsdesign på Bioanalytikeruddannelsen Metropol se Lorenzen og Thomasen (2017).
} 
Inden for sundhedsprofessioner som sygeplejerske og jordmoder, har man bl.a. i Australien anvendt portfolier som dokumentation for kontinuerlig kompetenceudvikling (Andre \& Heartfield, 2007). Med fokus på øget international mobilitet blandt sundhedsprofesionelle er der et stigende behov for at kunne dokumentere hvilken læring, der har fundet sted i forbindelse med formel og uformel kompetenceudvikling. Inddragelse af portfolien som et aktivt læringsredskab i forbindelse med uddannelse af kommende sundhedsprofessionelle, kan derved på sigt styrke den professionsudøvendes mulighed for refleksion over og dokumentation af livslang læring.

Barrett (2011) fremhæver i sin udlægning af de processer, der er involveret i arbejdet med digitale portfolier, to forskellige hovedaktiviteter; enten læring og samarbejde med fokus på processen eller portfolien som en præsentationsmappe eller eksamensportfolio med fokus på produktet. En digital portfolio er både proces og produkt. De fleste digitale portfolier lægger ifølge Barrett (2011) mest vægt på præsentationsdelen dvs. produktet, og mindre på læringselementet dvs. processen. Der ses en tendens til to forskellige måder at organisere en portfolio på afhængig af om fokus er primært produkt eller proces; enten tematisk som det ofte ses ved præsentationsportfolier, eller kronologisk som det ofte ses ved refleksionsportfolier.

På baggrund af underviserteamets egne erfaringer med portfolio og peer to peer feedback samt viden fra litteraturen, designede vi en model for portfolio og peer to peer feedback. Vi valgte at arbejde med en digital refleksionsportfolio, hvor formålet med portfolien var læring. Dvs. vi har bevidst fravalgt at benytte portfolien som eksamensportfolio med formativ evaluering, men valgt at anvende portfolien udelukkende som et læringsredskab.

Dysthe stiller følgende spørgsmål vedrørende indførsel af portfolio:

"Hvilken læringsanskuelse ligger til grund for organisering og tilrettelæggelse af læringsarbejdet? Hvilke typer opgaver får de studerende at arbejde med? Er samarbejde mellem studerende eller individuelt arbejde i fokus? Har de studerende indflydelse på læringsaktiviteterne?"

(Dysthe \& Engelsen 2005, s. 41)

Da vi besluttede os for at indføre portfolioarbejdet som en læringsaktivitet, gjorde vi os overvejelser om følgende:

- Hvor ofte skulle der afleveres portfoliobesvarelser?

- Hvordan skulle portfoliobesvarelserne afleveres?

- Skulle afleveringen være obligatorisk?

- Hvad skulle være styrende for indholdet af portfoliobesvarelsen? 
- Skulle portfolien være personlig eller offentlig?

- Hvem skulle have adgang til at læse portfoliobesvarelsen?

- Hvordan og af hvem skulle der gives feedback på portfoliobesvarelsen?

- Skulle portfoliobesvarelserne evalueres?

- Hvordan skulle portfolien introduceres til de studerende?

Vi overvejede, at portfolien skulle kunne understøtte det, som Mezirow (2012) betegner som instrumentel læring ved en hypotetisk deduktiv tilgang, som den enkelte studerende individuelt benytter sig af under udarbejdelsen af portfoliobesvarelsen. Desuden skulle portfolien understøtte kommunikativ læring og kritisk refleksion (Mezirow 2012), hvilket opstår ved peer to peer feedback på portfolien. Dvs. vi ønskede at omfavne både et kognitivt og et sociokulturelt perspektiv på læring.

Med afsæt i disse overvejelser blev det besluttet, at portfolierne løbende skulle afleveres (hver uge) så skrivearbejdet og efterfølgende feedback og refleksion også kunne ske løbende. Portfolien skulle afleveres i et format, så den var let tilgængelig for en eller flere feedbackmakkere og undervisere, den blev derfor digital. Da portfolien skulle benyttes individuelt af de studerende i forhold til kundskabskonstruktion mht. at opnå konkret viden og færdigheder, der er fastlagt af underviserne, valgte vi, at det også var underviserne, der skulle styre indholdet af ugens portfolio. Da portfolien skulle være et læringsredskab, skulle den ikke direkte evalueres af underviserne, men udelukkende evalueres af den studerende selv på baggrund af peerfeedback og efterfølgende dialog med medstuderende og undervisere. Herved ville vi opnå en højere grad af dialogisk kommunikation, hvilket læner sig op ad den dialogiske anskuelse af sprog og læring, som Dysthe giver udtryk for (Dysthe \& Engelsen, 2005). For at få maksimalt udbytte af læringspotentialet ved arbejdet med portfolien, valgte vi at introducere portfolien ved starten af undervisningsforløbet. Formål og rammer for portfolien skulle tydeligt formidles til de studerende, da det er vores erfaring, at meget tydlige rammer er fremmende for læringsudbyttet, når der eksperimenteres med nye læringsaktiviteter.

Inden introduktionen af portfolien i første undervisningsforløb i efteråret 2015 , havde vi truffet følgende valg vedr. design af den digitale portfolio:

\begin{tabular}{|l|l|}
\hline Hvad & Hvem \\
\hline Valg af indhold & Vælges af underviser \\
\hline Detaljeringsgrad & Vælges af den studerende \\
\hline Refleksion over læring & $\begin{array}{l}\text { Undervisere opfordrer til refleksion over læring, men det er } \\
\text { frivilligt for den studerende }\end{array}$ \\
\hline Anvendelse af refleksioner & Til den studerendes eget brug \\
\hline Feedback & Peer to peer, feedbackmakker vælges af den studerende \\
\hline Adgang til portfolio & Undervisere og feedbackmakker \\
\hline
\end{tabular}




\title{
Læring, transfer og portfolioarbejde
}

Bioanalytikeruddannelsen er en professionsbacheloruddannelse på 311/2 år, hvor undervisningen er tilrettelagt, så der sker en løbende progression af de studerendes viden, færdigheder og kompetencer inden for forskellige fagområder som f.eks. histologi, kemi, statistik, humanbiologi, molekylærbiologi mv. Uddannelsen til bioanalytiker finder sted i en vekselvirkning mellem undervisning på professionshøjskolen og praktik primært på hospitalslaboratorier, men også i forskningslaboratorier og private virksomheder.

På Bioanalytikeruddannelsen Metropol har vi længe arbejdet med problembaseret læring ud fra et konstruktivistisk læringssyn, hvor de studerende selv har været medskabere af læringsmål og efterfølgende kundskabskonstruktion (Lorenzen \& Thomasenm, 2017).

Med læring mener vi en proces, der finder sted, når en person tilegner sig ny viden, som knytter an til eksisterende viden og nye forståelser eller erkendelser nås. Dvs. læring kan både have assimilativ og akkomodativ karakter (Illeris, 2006). Læring kan også have transformativ karakter (Mezirow, 2012), hvilket vi i undervisningen på en professionsbacheloruddannelse tydeligt ser, når de studerende bliver i stand til at overføre læring mellem det teoretiske læringsrum (klasseværelset) og det praktiske læringsrum (undervisningslaboratoriet) og endelig til praksislæringsrummet (hospitalslaboratoriet), og de indtager den nye erkendelse som en del af deres professionsidentitet som bioanalytiker. Det har været en udfordring for de praksisnære professionsuddannelser herunder Bioanalytikeruddannelsen at opnå denne transfer mellem uddannelsesinstitution og praksis (Nielsen \& Månsson, 2011).

For at beskrive graden af læring kan man benytte sig af en taksonomi, der søger at beskrive erkendelsesformer på forskellige niveauer. Biggs \& Tang (2007) har udviklet en taksonomi, SOLO taksonomien, der afviger en smule fra den klassiske Blooms taksonomi.

\author{
"SOLO, which stands for Structure of the Observed Learning \\ Outcome, provides a systematic way of describing how a \\ learner's perfomance grows in complexity when mastering many \\ academic tasks." \\ (Biggs \& Tang 2017: 76)
}

I Biggs' taksonomi lægges der vægt på, hvorledes de ideer eller den viden, man har, er koblet (unistructural eller multistructural) og kan anvendes til at forstå sammenhænge (relational) eller kan bruges til at generere helt nye ideer (extended abstract). Denne taksonomi er i dag meget anerkendt, f.eks. er det et krav, at mål for læringsudbytterne ved de nye sundhedsuddannelser skal beskrives efter SOLO taksonomien. 


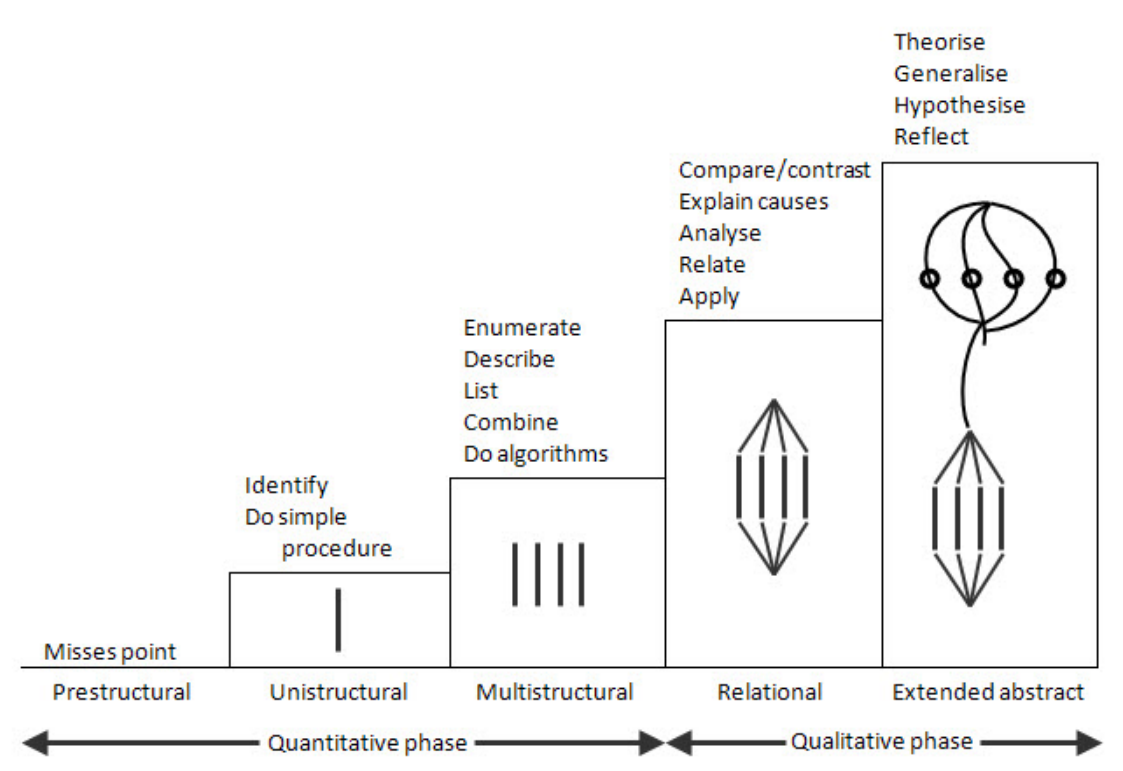

Figur 2. SOLO taksonomi. Et hierarki af verber, der kan bruges til at danne læringsmål. Unistrukturel læring betegner læring i den kvantitative fase, som er kendetegnet ved overfladelæring, hvor begreber kan identificeres, men ikke kombineres med parallelle begreber. Extended abstract er et udtryk for meget dyb viden, hvor den studerende kan kombinere viden på tværs af fag, teori og praksis, og kan udlede nye teorier og forståelser (Biggs \& Tang, 2007, s. 79).

For at nå højt op på SOLO taksonomien er det en forudsætning at gennemføre en aktiverende undervisning, der inddrager de studerende, og $\mathrm{i}$

undervisningssituationen sætter deres viden i spil således, at de får mulighed for at konstruere ny dyb viden og ikke blot tilføjer ny overfladisk viden. Dette hænger godt sammen med det overvejende konstruktivistiske læringssyn, der generelt er fremherskende på professionsbacheloruddannelser, hvor det forventes, at de studerendes læring er koblet til praksis.

En aktiverende undervisningsform kommer alle studerende til gode, men i særdeleshed kan det være med til at løfte niveauet for gruppen af mindre engagerede studerende (figur 1), der ikke udviser særlig interesse for læringsprocessen, men har som det primære mål at bestå eksamen og dermed få et diplom som giver adgang til en autorisation, så de kan udøve professionen og blive en del af arbejdsmarkedet.

Under processen med at udarbejde et indlæg til den digitale portfolio inkorporeres den studerendes opfattelse af tilegnet viden og færdigheder med en meningstilskrivelse, som under skriveprocessen af portfolien medfører en forståelse ved en kognitiv proces, som kan inkludere restrukturering af tidligere forståelse, bekræftelse af hvad man allerede ved, samt øger bevidstheden om hvilken viden, færdigheder eller kompetencer, man skal have for at kunne udarbejde en komplet besvarelse. 
Ved det skriftlige arbejde med en digital portfolio er det vores intention, at de studerende bliver bevidstgjort om at anvende viden fra praksis i forhold til teori og omvendt. Desuden kan portfolien via konkret stillede portfolioopgaver meget konkret lægge op til, at de studerende foruden at kunne reproducere grundlæggende viden (lavt SOLO niveau) også skal kunne reflektere over den tilegnede viden og vurdere, om den kan anvendes til at forklare eller analysere problemstillinger (højt SOLO niveau) og dermed opnå dybere viden, hvilket også er det, vi søger at afdække ved den skriftlige eksamen.

Det er således vores opfattelse at indføring af en digital portfolio som undervisningsaktivitet, kan aktivere studerende til højere grad af læring.

\section{Peer to peer feedback på portfolio}

Tankerne bag peer to peer feedback på portfolierne tydeliggøres af dette citat fra Hattie:
"Mennesker, der lærer, har en enorm gavn af sociale eksempler, styret undervisning og korrektiv feedback. At lære ved at blive eksponeret for information fra andre mennesker repræsenterer et fundamentalt aspekt, der underbygger menneskelig tilpasning og evolution; jo mere disse "andre mennesker" bliver eksperter i forståelsen af læringens progression, jo mere effektiv er læringen. Dette er den grundlæggende ide for social læring." (Hattie, 2014, s. 20)

Øget feedback har senest været et væsentligt tema i hele uddannelsessektoren. Senest har Danske Professionshøjskoler (2016) udgivet et idékatalog om feedback. For at feedback er effektivt og bidrager til læring, skal den finde sted, mens den studerende stadig har interesse for opgaven, være styret af klare mål, og skal være retningsgivende i forhold til fremtidige forbedringer (Hattie, 2014).

Fra et tidligere ansættelsesforhold på et internationalt gymnasium med International Baccalaureate Diploma Programme havde en af forfatterne af denne artikle gode erfaringer med skriftlig peer to peer feedback, og teamet valgte at introducere denne model. Erfaringen var, at peer to peer feedback medfører, at den studerende er motiveret til at yde et godt stykke arbejde, da det skal vises til en medstuderende. Det var også erfaringen, at der er meget læring i det at give feedback, bl.a. fordi den studerende, der skal give feedback, først selv skal være meget bevidst om målet med opgaven, for at være i stand til at give feedback inden for denne ramme. Dernæst skal den, der giver feedback selv have en forståelse, der mindst er på niveau med det faglige niveau i opgaven. Hvis personen, der giver feedback, ikke har så udviklet en forståelse for emnet, kan der også ligge meget læring i at studere, hvordan en medstuderende har grebet besvarelsen af en kompleks opgave an. Ved at 
introducere portfolio koblet med peer to peer feedback håbede vi derved at kunne opnå øget motivation blandt de studerende og hermed også et øget engagement og en højere studieintensitet.

Underviserteamets læringssyn ligger op ad konstruktivismen og den dialektiske materialisme som bl.a. Vygotsky står for (Illeris, 2006). Dette er interessant i denne sammenhæng, da Vygotsky også fokuserer på sproget som en del af læring. Sproget er bestemmende for det, man tænker, og ved læring tilegner man sig i første omgang et nyt sprog, mens man i anden omgang kobler flere sprog sammen i en større forståelse. Derfor lægger Vygotsky også meget vægt på, at man i tilrettelæggelse af læring skal have for øje at ramme de studerendes zone for nærmeste udvikling. På Bioanalytikeruddannelsen på Metropol har vi en del studerende med andet modersmål end dansk og flere ordblinde studerende, for hvem arbejdet med skriftligt fagsprog er en udfordring. Hvis ikke de studerende har tilstrækkelig viden, eller et tilstrækkeligt fagsprog mistes motivationen, og der finder ingen læring sted. Udfordrer man dem til gengæld på et niveau, der ligger over deres eget niveau, men som de ud fra klare målformuleringer kan se, at de har mulighed for at kunne nå, vil dette i sig selv være en drivkraft for læring.

Drivkraft for læring er afgørende for at kunne øge de studerendes engagement. Illeris (2006) har i sin model for læringens dimensioner drivkraften som én af tre dimensioner. Læringstrekanten (figur 3) er en skematisk illustration af læringens tre dimensioner, det kognitive (indhold), det affektive (drivkraft) og samspillet mellem individet og omgivelserne.

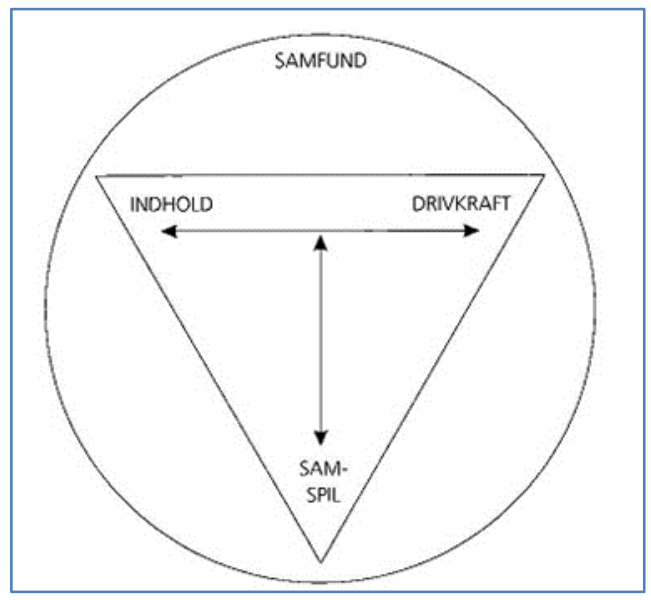

Figur 3. Illeris læringstrekant (Illeris, 2006, s. 39)

Vi har i planlægningen af portfolioarbejdet og efterfølgende peer to peer feedback haft fokus på alle tre dimensioner. De studerende skal hver især forholde sig til indholdsdelen af modulet, og vi har forsøgt at balancere den faglige udfordring, så den bliver en drivkraft i sig selv. Den studerendes læringsprocesser finder således sted som både en individuel kognitiv proces under udarbejdelse af portfolien og efterfølgende skriftlig peer to peer 
feedback samt en mere socialkonstruktivistisk proces i samspil med både undervisere og medstuderende i forbindelse med feedbacken.

Effekten af feedback er nøje undersøgt af Hattie og Timperley (2007), som har fundet frem til, at de mest effektive former for feedback angiver nøgleord, der beskriver, hvad man bør gøre (instructional feedback), samt relaterer sig til specifikke mål. Hattie og Timperley (2007) opdeler feedback i fire niveauer; rettet mod indhold samt rigtige og forkerte svar, rettet mod forståelse og sprog, rettet mod den studerendes studiekompetencer og endelig rettet mod den studerende som person.

For at den studerende aktivt lærer fra feedbacken, er det vigtigt, at feedbacken ikke truer ens selvværd, da trygge rammer tillader, at ens opmærksomhed bliver rettet mod feedbacken (Hattie \& Timperley, 2007). Derfor blev det besluttet, at der ved første feedbacksession skulle være dialog mellem studerende og undervisere om god digital omgangstone, hvad der kan opleves som fremadrettet konstruktiv feedback, der kan bidrage til læring. Desuden tydeliggøres det, at portfolien er et læringsredskab, der deles med studerende, som den studerende selv har valgt.

Efter at underviserteamet havde gjort sig overvejelser om de læringsanskuelser, der ligger til grund for den undervisning, vi ønskede at gennemføre, graden af samarbejde mellem studerende i forbindelse med de individuelt udarbejde portfoliobesvarelser, og de studerendes grad af indflydelse på arbejdet med portfolien, var vi klar til at gå i gang med det mere konkrete design af den digitale portfolio og peer to peer feedback på modulet "Molekylærbiologiske og genetiske analyser".

\section{Casen: Design af en digital portfolio og peer to peer feedback}

\section{Udvikling af modulet "Molekylærbiologiske og genetiske analyser"}

Modulet "Molekylærbiologiske og genetiske analyser" ligger som modul 9 (M09) ud af i alt 14 moduler i begyndelsen af tredje år på

Bioanalytikeruddannelsen på Metropol. Modulet afvikles hvert halve år med 50-75 studerende på modulet. De studerende har alle på dette tidpunkt i deres uddannelse arbejdet med problembaseret læring, de har gennemført projektarbejde, de har en del laboratorieerfaring, og de har alle deltaget $\mathrm{i}$ praktikophold flere gange på forskellige hospitalslaboratorier. Følgende formål fra Studieordning for uddannelsen til Professionsbachelor i Biomedicinsk Laboratorieanalyse skal opfyldes under dette modul:

\footnotetext{
"Formål: Modulet giver den studerende fundamental viden om genetik samt viden om principperne bag og kvalifikationer til at udføre repræsentative molekylærbiologiske teknikker. Kernen i modulet er, at den studerende opnår en reflekteret forståelse af
} 
hvordan og hvornår molekylærbiologiske teknikker kan og bør anvendes i forbindelse med genotypning, screening, diagnostik og behandling."

(Studieordning for uddannelsen til Professionsbachelor i Biomedicinsk Laboratorieanalyse, juli 2009)

Modulet, som er på 15 ECTS, løber over 9 uger og afsluttes med en tre timers individuel skriftlig eksamen. Undervisningen varetages af adjunkter og lektorer på Bioanalytikeruddannelsen. Modulet blev oprindeligt udviklet i tæt samarbejde med praksis. Vi var et team på fire undervisere, der sammen videreudviklede, planlagde og gennemførte undervisningen på modulet med henblik på en faglig opdatering og en didaktisk ændring med inddragelse af digital portfolio og peer to peer feedback.

For at få mere aktive og engagerede studerende valgte vi at omlægge laboratoriearbejdet fra traditionelle laboratorieøvelser med $\emptyset$ velsesvejledninger til i stedet at indgå som en del af et mere projektorienteret forløb, hvor de studerende selv skulle planlægge, udføre og vurdere resultater fra grundlæggende molekylærbiologiske analyser. De studerende blev derved i højere grad partnere i tilrettelæggelsen af laboratorieaktiviteterne og derved medskabere af egen læringssituation, hvilket efterfølgende skulle formidles i deres portfolio. Studerende som medskabere virker fremmende for engagementet (Cook-Sather et al, 2014), og kan derved i sig selv virke som en drivkraft for læring.

Udviklingen af modulet blev påbegyndt i foråret 2015, og det nye modul 9 blev afholdt første gang i efteråret 2015 og er siden blevet afholdt en gang hvert halve år. Modulet følger strukturen angivet i figur 4 og 5 . Hvert tema løber over en uge med PBL-opstart, faglige oplæg (FO), laboratoriearbejde (lab), workshops (WS), feedback og PBL-afslutning, hvor de studerende kan arbejde med planlægning af laboratoriearbejde, ugens læringsmål, det gennemgående projekt eller portfolioopgaver. Modulet er struktureret i fire PBL-forløb med hver to temaer af en uges varighed og projektarbejde i den niende uge. De første otte uger er struktureret nogenlunde ens, som illustreret i idealskema for uge 2 (figur 5). 


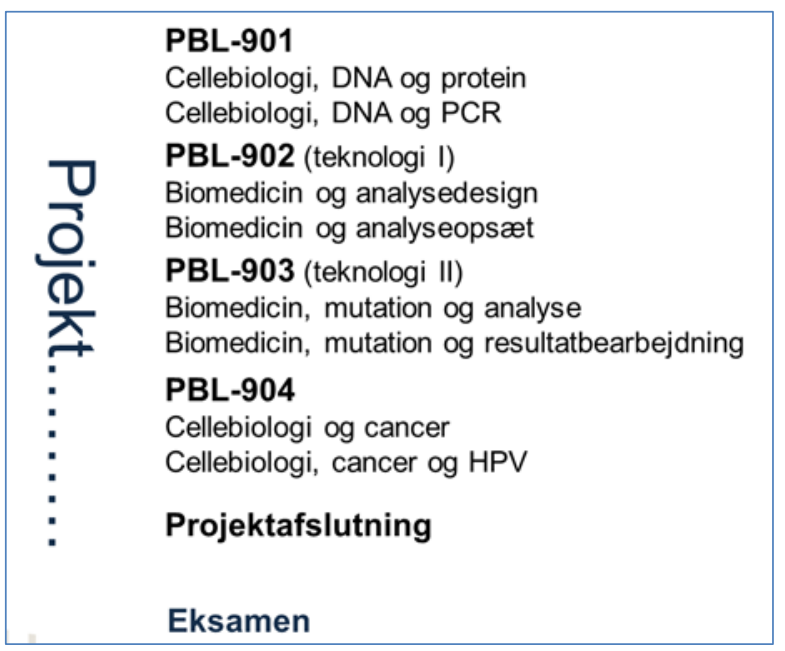

Figur 4. Struktur over 10-ugers forløbet på modul 9. Forløbet er struktureret i fire PBL-forløb, der hver er opdelt i to temaer af en uges varighed. Arbejdet med det gennemgående projekt løber parallelt med de sidste tre PBL-forløb samt i den sidste uge.

\begin{tabular}{|c|c|c|c|c|c|}
\hline Lektion & Mandag & Tirsdag & Onsdag & Torsdag & Fredag \\
\hline 1 & $\begin{array}{l}\text { PBL opstart } \\
\text { Vejlederen er hos } \\
\text { PBL-grupperne } \\
\text { ca. } 20 \text { min, til } \\
\text { initiering af } \\
\text { opstart og evt. } \\
\text { ramme- og } \\
\text { begrebsafklaring }\end{array}$ & $\begin{array}{l}\text { WS } \\
\text { Arbejde m egne } \\
\text { læringsmål og } \\
\text { portfolio. } \\
\text { Planlægning af } \\
\text { laboratorie- } \\
\text { arbejde. }\end{array}$ & $\begin{array}{l}\text { WS/lab } \\
\text { Arbejde m egne } \\
\text { læringsmål og } \\
\text { portfolio. } \\
\text { Planlægning og } \\
\text { gennemførelse af } \\
\text { laboratorie- } \\
\text { arbejde }\end{array}$ & $\begin{array}{l}\text { WS/lab } \\
\text { Arbejde m egne } \\
\text { læringsmål og } \\
\text { portfolio. } \\
\text { Planlægning og } \\
\text { gennemførelse af } \\
\text { laboratorie- } \\
\text { arbejde }\end{array}$ & $\begin{array}{l}\text { WS portfolio } \\
\text { feedback } \\
\text { Peer-feedback og } \\
\text { selvevaluering af } \\
\text { portfolioprodukt }\end{array}$ \\
\hline 2 & PBL opstart & WS & WS/lab & WS/lab & $\begin{array}{l}\text { WS portfolio } \\
\text { feedback }\end{array}$ \\
\hline 3 & $\begin{array}{l}\text { WS } \\
\text { Afklaring af om } \\
\text { læringsmål er } \\
\text { fyldestgørende } \\
\text { for modulets } \\
\text { faglige krav }\end{array}$ & $\begin{array}{l}\text { FO } \\
\text { Cellecyklus og } \\
\text { replikation }\end{array}$ & WS/lab & WS/lab & $\begin{array}{l}\text { PBL afslutning } \\
\text { Diskussion af } \\
\text { læringsmål i } \\
\text { gruppen uden } \\
\text { underviser }\end{array}$ \\
\hline 4 & & $\begin{array}{l}\text { FO } \\
\text { PCR }\end{array}$ & WS/lab & WS/lab & PBL afslutning \\
\hline 5 & & WS & WS/lab & WS/lab & $\begin{array}{l}\text { PBL afslutning } \\
\text { Feedback fra } \\
\text { underviser }\end{array}$ \\
\hline
\end{tabular}

Figur 5. Idealskema for uge 2 F16. WS: workshop, FO: fagligt oplæg, lab: laboratoriearbejde.

\section{Portfoliodesign}

For at koble de studerendes læringsproces med aktivt brug af både skriftligt og mundligt fagsprog valgte vi at tilføje et nyt element i modulet: den digitale portfolio. Portfolioarbejdet var en helt ny dimension for de studerende. Vi valgte, at de studerende skulle lave personlige portfolier, hvor de individuelt kunne træne deres skriftlige fagsprog. For at få feedback på portfolien valgte vi at benytte os af peer to peer feedback kombineret med generel feedback fra to undervisere i plenum ved feedback-workshops. 
Overvejelserne beskrevet ovenfor er alle fortaget med udgangspunkt i de forventninger, vi har til de studerendes læringsforudsætninger. Alle i udviklingsteamet underviser også studerende på Bioanalytikeruddannelsens tidligere moduler, og har på den baggrund en afstemt forventning til de studerendes viden, færdigheder og kompetencer, når de når til modul 9, og kan ligeledes sikre progressionen i de studerendes læring.

Med udgangspunkt i disse ændringer var det udviklingsteamets ambition, at de studerende ville udvise højere motivation og studieintensitet. Planer og mål for udviklingen af modulet blev beskrevet som to eksperimenter under Metropols strategiske satsning på 'intense studier' (Professionshøjskolen Metropol, 2014). Eksperimentet "Styrkelse af de studerendes studiekompetencer og forståelse for eget fagligt niveau" blev afviklet i efteråret 2015. Erfaringer blev indsamlet, og eksperimentet blev gennemprøvet igen i foråret 2016 med justeringer og øget fokus på portfolien og feedback: "Feedback og digital portfolio på modul 9 Bioanalytikeruddannelsen".

Det er på Bioanalytikeruddannelsen på Metropol besluttet, at en del af uddannelsens udprøvninger skal være skriftlige, og det er besluttet, at modul 9 eksamen er en af disse skriftlige eksamener. Underviserteamet udarbejdede i fællesskab skriftlige eksamensopgaver til summativ vurdering af de studerendes læring. Eksamenssættet var tilrettelagt med ligelig fokus på teori og praksis med anvendelse af begreber fra Biggs' taksonomi (figur 2) såsom beskriv eller forklar, således at vi kunne afdække både overfladisk og dybere forståelse af emnerne. For at opnår alignment var der en direkte sammenhæng mellem de skriftlige formuleringer i opgaverne stillet til eksamen og de opgaver, der blev stillet i de ugentlige portfolioopgaver.

I portfolioopgaverne blev de studerende også bedt om at inddrage deres praksiserfaringer fra laboratoriet ved f.eks. at beskrive deres planlægning eller forklare deres resultater fra laboratorieøvelserne ved at anvende teori og derved reflektere over generaliserbarhed af indsamlet empiri i forhold til teorigrundlag. Herved skabes der vha. portfolien en mulighed for de studerende for at bevæge sig op ad SOLO taksonomien til extended abstract.

Dette var også med til at øge graden af alignment i modulet, da de studerende herved skulle koble teoretisk viden med det praktiske arbejde fra laboratoriet. Se også de to eksempler på hhv. den tredje og syvende portfolioopgave ud af i alt otte (figur 6). 


\section{Portfolio-opgave 902-1}

I forbindelse med forløbet "PBL 902-1 Projektvalg og Primer design" vil vi bede jer forholde jer til følgende spørgsmål i forbindelse med jeres portfolioaflevering fredag:

- $\quad$ Primeropgave fra primerintro torsdag. I skal aflevere jeres løsning på opgaven i form af en tegning/figurer af primerne og PCR-opformering på baggrund af de designede primere. De enkelte trin i både design af primere og PCR skal beskrives i detaljer i jeres aflevering.

- Dokumentation og refleksioner over det endelige valg af primere til opformering af PCR-fragment i forbindelse med den genetiske sygdom I har valgt at arbejde med i jeres projekt. Beskriv detaljeret og præcist gruppens arbejde med primerdesign. Hvad har været udgangspunktet for primerdesign; artikler/litteratur, DNA sekvenser, databaser, software... osv. Hvad har i haft af tekniske overvejelser i forbindelse med design af primere?

- Dokumentation i forhold til projektvalg. Jeres portfolioaflevering skal indeholde problemfelt, projektoplæg som kort introducerer emnet og beskriver baggrund for valg af emne. Oplægget skal desuden inkludere en liste over artikler m.v., som I/projektgruppen indtil nu har fundet ved litteratursøgning.

Jeres portfolio-besvarelse skal uploades til IntraPol fredag, så den ligger klar til den efterfølgende peerfeedback workshop.

\section{Portfolio-opgave 904-1}

I forbindelse med forløbet "PBL 904-1 Cellebiologi og Cancer" vil vi bede jer forholde jer til følgende spørgsmål i forbindelse med portfolio aflevering fredag.

- Beskriv funktionen af de cellecyklusspecifikke cyklin-afhængige kinaser (CDK'er), og hvordan de reguleres af henholdsvis cykliner og reversibel fosforylering (alle væsentlige detaljer skal med i besvarelsen).

- Beskriv med udgangspunkt i en normalt fungerende celle passage hen over G1-checkpoint. Forklar herunder i detaljer funktionen af Rb og E2F. Forklar ligeledes p53's funktion/rolle ved DNA-skade.

- Definer et proto-onkogen, et onkogen og et tumorsuppressorgen. Forklar herunder gain-offunction - mutationer og loss-of-function - mutationer.

- Forklar om følgende proteiner er produkter af proto-onkogener eller tumorsuppressorgener, begrund svaret: CDK'er, p53, RB og E2F.

- Vis/medtag de opstillede PBL-læringsmål, der har understøttet jeres læringsproces i forbindelse med besvarelsen af denne uges portfolio.

Jeres portfolio-besvarelse skal senest uploades til IntraPol fredag, så den ligger klar til den efterfølgende peerfeedback workshop. I workshoppen vil vi fokusere på, hvordan I har forstået og besvaret opgaven, og hvad vi som undervisere har ment, da vi stillede opgaven.

Vores peerfeedback workshop er yderst eksamensrelevante, da vi her har mulighed for $i$ fællesskab, at tale forståelse, niveau, sproglig og faglig præcision... osv. Der er stadig plads til flere, der tør og vil udfordre sig selv og samtidig forberede sig på eksamen... velkommen på fredag.

Figur 6. To eksempler på ugentlige portfolioopgaver ud af i alt otte portfolioopgaver. 


\section{Digitalisering af portfolien}

I samarbejde med Supportenhed for Digital Læring på Metropol udarbejdede vi rammerne for den digitale portfolio. Målet var, at portfolien skulle være koblet til det digitale Learning Management System, IntraPol, som alle studerende og undervisere på Metropol benytter sig af. Portfolien skulle være personlig for at skabe et trygt arbejdsrum, og for at få peerfeedback skulle de studerende selv vælge en eller to feedbackmakkere, som de gav adgang til deres portfolio. De blev opfordret til at finde sammen med en feedbackmakker, som de ikke normalt arbejdede sammen med, så de kunne få nye perspektiver på deres opgavebesvarelse.

Den tekniske del af opsætningen blev de studerende guidet igennem af en underviser på modulet understøttet af en trin for trin vejledning med screenshots af relevante skærmbilleder fra IntraPol. Samtidig med dette blev de studerende introduceret til formål, krav og rammer for portfolioarbejdet på modulet.

Vi valgte at gøre portfoliobesvarelserne obligatoriske, dvs. de studerende skulle hver uge aflevere en portfoliobesvarelser (i alt otte) for at kunne blive indstillet til eksamen. Vi stillede dog ingen krav til omfanget af besvarelserne, men tydeliggjorde for de studerende, at arbejdet med portfolioopgaverne skulle ses som et læringsredskab og i sidste ende en god notesamling. Da portefolioopgaverne i mange tilfælde afspejler mulige eksamensspørgsmål, gjorde vi opmærksom på, at der ville være en direkte sammenhæng mellem arbejdet, der blev brugt på portfolierne og opnåelse af modulets mål for læringsudbytter. Således var det intentionen at gøre målet med portfolien meget tydelig og specifik, hvilket også fremhæves af Hattie og Timperley (2007) som en forudsætning for effektiv feedback.

Den digitale refleksionsportfolio, der er en integreret del af Metropols Learning Management System, IntraPol, egner sig bedst til korte beskeder og links. Da vi havde en klar forventning om lange opgavebesvarelser, valgte vi, at en besvarelse i den digitale portfolio skulle indeholde et link til den studerendes besvarelse, som de havde skrevet i et delt dokument i Office 365, som alle de studerende på Metropol har adgang til via IntraPol. Senere blev det også muligt at uploade pdf- og word-filer i den digitale portfolio.

For at gøre den personlige refleksionsportfolio overskuelig både for de studerende, feedbackmakkere og undervisere blev der opstillet tydelige rammer for, hvordan portfolioafleveringerne skulle afleveres. De studerende skulle hver især oprette en personlig digital mappe via Metropols Learning Management System, som de skulle give feedbackmakker og undervisere adgang til. Denne mappe skulle navngives med den studerendes for- og efternavn samt gruppenummer, dvs. f.eks. Hans Hansen 9A. Dette gjorde det overskueligt for underviserne, som havde adgang til alle studerendes portfolier, at skelne mellem dem. Desuden skulle hver ny portfolioaflevering 
navngives med en titel svarende til nummeret på ugens forløb, f.eks. 901-1, 901-2, 902-1 osv. Denne organisering gjorde det let at navigere i den kronologiske tråd, som den digitale refleksionsportfolio på Metropols Learning Management System, IntraPol, automatisk bliver organiseret i.

\section{Design af peer to peer feedback på portfolio}

Det var et klart valg, at portfolien skulle have form af en arbejds/refleksionsportfolio og ikke en præsentationsportfolio, dvs. der skulle i arbejdet med portfolio være meget fokus på proces, herunder processen med at tilegne sig viden og opbygge en kobling af forståelsen mellem arbejdet i laboratoriet og de teoretiske elementer i undervisningen. Dvs. vi ønskede at lægge vægt på den formative feedback og mindre på vurdering og summativ tilbagemelding. Da der er stor læring forbundet med at give og modtage feedback, valgte vi, at den primære feedback på portfolien skulle være peer to peer feedback.

De studerendes forståelse afprøves via portfolioarbejdet ved, at den studerende reflekterer over en anden studerendes begrebsliggørelse og skriftligt giver et respons på, hvorledes de to studerendes forståelse for emnet divergerer fra hinanden. Dernæst vil den ene studerende over for den anden studerende mundligt forklare den nye erkendelse eller stille uddybende spørgsmål til forståelsen. Dette finder sted i slutningen af feedbackworkshoppen, og den mundtlige dialog fortsætter ved de efterfølgende PBLafslutninger.

I nogle tilfælde indeholder den skriftlige portfolioaflevering beregninger og beskrivelser, der ligger til grund for det efterfølgende laboratoriearbejde, og den studerende vil således efterfølgende selv erfare i praksis, om beregningerne og beskrivelserne af f.eks. arbejdsgange i laboratoriet er korrekte og fyldestgørende. Der åbnes derved op for transfer mellem teoretisk forberedelse og praktisk udførelse af det molekylærgenetiske analysearbejde i laboratoriet.

En risiko ved fokus på peer to peer feedback sammenlignet med feedback fra en underviser er fejllæring og overfladisk læring, da feedbacken måske ikke er tilstrækkelig kvalificeret eller den studerende ikke er i stand til at gøre brug af feedbacken pga. modstand (affektiv) eller mangel på forståelse (kognitiv). Derfor valgte vi at tilbyde ugentlige feedback workshops, hvor peer to peer feedback blev faciliteret af en underviser under fastlagte rammer. Hver fredag var der afsat to lektioner (2x45 min) til en feedback workshop. I løbet af den første lektion skulle de studerende læse en medstuderendes portfolioaflevering og uden yderligere indbyrdes kommunikation give skriftlig feedback til den medstuderende med fokus på følgende: fagligt niveau, faglig forståelse, struktur/overblik samt læsevenlighed. Dette svarer til to af de fire niveauer for feedback beskrevet af Hattie og Timperley (2007) nemlig feedback i forhold til hhv. indhold og forståelse. Underviserne tydeliggjorde 
ved feedback-workshoppen, at feedbacken skulle have en konstruktiv fremadrettet evt. spørgende karakter, og at de studerende ikke skulle vurdere hinandens arbejde eller rette hinandens opgaver. De studerende blev også opfordret til at anbefale hinanden litteratur, videoer eller andet, der havde fremmet deres egen læring. Dernæst havde de studerende tid til at drøfte hinandens besvarelser og feedback. I anden lektion var der feedback i plenum fra underviserne og en generel opsamling på ugens portfolioafleveringer. De studerende fik udleveret følgende rammer for feedback:

\section{Portfolio og feedback}

I starter med at læse den portfolio, I skal give feedback på igennem, og forholder jer til det I læser. Herefter, eller undervejs, giver i skriftligt feedback på det læste. Husk det er ikke meningen i skal rette hinandens portfolio.

Vær konstruktiv og imødekommende i jeres feedback! Det handler om, at I skal lære mest mulig. Bliv inspireret af hinanden. Det er jer selv, der sætter standarden, har man i en uge ikke nået så meget, er portfolien måske ikke så detaljeret/udbygget.

I kan f.eks. give feedback på følgende:

- $\quad$ Fagligt niveau

- Faglig forståelse

- Struktur/overblik

- $\quad$ Læsevenlighed

Herefter læser I jeres egen kommenterede portfolio igennem, og sammen laver vi i plenum en opsamling på portfolio-opgaven. Opsamlingen bliver baseret på de spørgsmål, I måtte have efter feedback fra jeres medstuderende.

Tidsplan:

1. 40 min. Gennemlæsning og skriftlig feedback på portfolio

2. 20 min. Gennemlæsning af egen portfolio og refleksion over feedback. Kommentarer/spørgsmål til opsamling

3. 25-30 min. Opsamling af portfolioopgave.

I skal se tilbuddet om feedback fra medstuderende og undervisere som en del af en god eksamensforberedelse.

Mvh. Modul 9 underviserne.

Figur 7. Rammen for peer to peer feedback på den digitale portfolio.

Feedbacken foregik således i to rum, et digitalt rum med peer to peer feedback og et fysisk rum med mulighed for efterfølgende afklaring og uddybning af feedbacken og opgavebesvarelserne fra både medstuderende og undervisere.

Rammen for portfolien og efterfølgende feedback er blevet diskuteret løbende i underviserteamet. Vi havde til at starte med i efteråret 2015 ikke været tilstrækkelig tydelige i forhold til rammerne, da vi i høj grad opfattede portfolien som den studerendes eget instrument til læring. I takt med, at modulet blev gennemført gentagne gange, blev rammen løbende gjort tydeligere. 


\section{Undersøgelsesdesign af effekten af portfolio og peer to peer feedback}

Siden vi startede på udviklingen af det nye modul 9, har vi systematisk indsamlet viden for løbende at kunne lære af vores erfaringer og justere modulet. Følgende data er indsamlet:

- Fremmøderegistrering foretaget af underviser ved feedback-workshop

- Karakter

- Modulevaluering med både kvantitative og kvalitative data, der følger Metropols evalueringskoncept og afholdes efter hvert endt modul via Metropols Learning Management System

- Udpluk af portfoliobesvarelser via Learning Management System

- Løbende kvalitativ vurdering af den skriftlige peer to peer feedback via Learning Management System

- Registrering af hvilke studerende, der gav og modtog skriftlig feedback via Learning Management System

Data er blevet indsamlet fra modulerne afholdt i efterår 2015, forår og efterår 2016 samt forår 2017. I maj 2017 var data for karakterer endnu ikke tilgængelige. I alt er der indsamlet data fra 224 studerende, 53 (E15), 71 (F16), 56 (E16) og 44 (F17). Svarprocenten fra modulevalueringerne var $77 \%$ (E15), 66 \% (F16), 63 \% (E16) og 7 7\% (F17). Besvarelsesprocenten for de fire evalueringer vurderes som tilfredsstillende.

Desuden har vi sammenlignet modulevalueringer foretaget i slutningen af modul 9 med tilsvarende modulevalueringer foretaget i slutningen af modul 8 for de sidste to årgange, der har gennemført modul 8 og 9, for derved at kunne undersøge betydningen af forskellige studieaktiviteter for den samme gruppe studerende. I alt er der indsamlet data fra både modul 8 og 9 fra 102 ud af de 224 studerende, 58 (V16) og 44 (S17). Svarprocenten fra modulevalueringerne var 95 \% (V16) og 77 \% (S17). Besvarelsesprocenten for de to evalueringer vurderes som tilfredsstillende.

\section{Analyse og diskussion af resultater}

\section{Erfaringer med anvendelse af digital portfolio og peer to peer feedback}

Da modulet blev afviklet første gang i efteråret 2015 fik alle studerende oprettet en digital portfolio og afleveret besvarelser, men da vi var ca. halvvejs gennem modulet havde ca. $20 \%$ af de studerende endnu ikke fået skriftlig peerfeedback. Nogle af de studerende synes, at den digitale dimension var kompliceret. De blev dog alle i løbet af modulet fortrolige med at bruge de nye digitale værktøjer, som de kan få glæde af senere på uddannelsen og efter endt uddannelse. Således har vi med den digitale portfolio også været med til at øge fokus på digitalisering, hvilket vil komme de kommende bioanalytikere til gavn, da det meste af det apparatur, de anvender på hospitalslaboratorier eller i privat lægepraksis, betjenes fra en digital platform. 
De studerende havde ikke fra tidligere på studiet erfaring med at give peer to peer feedback. De troede først, at ideen var, at de skulle rette hinandens portfoliobesvarelser. På den baggrund præciserede underviserne, at de studerende skulle give hinanden fremadrettet, konstruktiv kritik som kunne hjælpe deres feedbackmakker med at løfte niveauet i deres opgaver. Via en skriftlig vejledning og yderligere uddybning på en feedback-workshop bad vi de studerende om at forholde sig til følgende parametre i forbindelse med den skriftlige peer feedback: fagligt niveau, faglig forståelse, struktur/overblik og læsevenlighed.

Flere studerende har særligt de første gange, vi afholdt modelet, udtrykt utryghed forbundet med det skriftlige portfolioarbejde. Særligt studerende, der følte sig udfordret i skriftlig dansk, oplevede det som et voldsomt krav, at de skulle udfærdige en skriftlig besvarelse en gang om ugen, som de tilmed skulle vise en medstuderende. Men efter de havde gjort det nogle gange, blev de fleste mere fortrolige med portfolien og knapt så sårbare i forhold til at formulere sig skriftligt. Arbejdet med fagsproget og den dialogiske kommunikation (Dysthe \& Engelsen, 2005) var således med til at styrke læringen. Der var dog nogle studerende, der ikke fik feedback af medstuderende, hvilket kan være et udtryk for, at de var blufærdige i forhold til at "udstille" deres skriftlighed. Flere studerende har fortalt, at de oplevede portfolien som et stort pres, men efter de havde kastet sig ud i det, oplevede de, at deres faglighed og skriftlighed var blevet styrket ved at skrive de ugentlige portfolier. Vi har som undervisere læst mange stikprøver af peerfeedbacken, nedenfor er gengivet et par eksempler:

"Jeg syntes at dit afsnit om sekventering var meget underholdende skrevet!!! Inspireret af Zombie-rack? Dit afsnit om forskellige mutationer og sekventeringsresultater er noget kort! Syntes bl.a. at du mangler beskrivelse af hvordan kurven ser ud. Ellers syntes jeg at det generelt er godt skrevet, og er ikke voldsomt uenig i noget af det du har skrevet :)"

\footnotetext{
"Spørgsmål 1: Fint afsnit der viser god forståelse for virus virkning på cellerne. Jeg mener dog der mangler en forklaring på et episom og hvordan virus reproduceres i cellerne og derfra kan inficere nye celler. Endvidere synes jeg der mangler nogle detaljer der forklarer at det først er når virus er blevet integreret i cellens genom at det kan udvikle sig til kræft. Spørgsmål 2: Rigtig fint med en kort beskrivelse af p53 og pRb's funktion i cellecyklussen og virussens påvirkning hertil. Dog mener jeg at virus først kan overtage cellecyklussen når det er integreret $\mathrm{i}$ cellens genom. Jeg ville ikke sige at E6 og E7 nedbryder p53 og pRb, men inaktivere dem derimod. Spørgsmål 3: Kort men godt. Spørgsmål 4: Godt sprog og fin beskrivelse. Spørgsmål 5: Rigtig
} 
fint besvarelse. Dog bliver peroxidase ikke omsat til produkt, men derimod substratet der tilsættes, som omdannes til produkt af enzymet. Dog kunne man evt. uddybe fortolkning af resultatet der opnås. Spørgsmål 6: Fint. Alt i alt en fin besvarelse med enkelte mangler :-)"

(Peer to peer feedback fra studerende)

Som det fremgår af eksemplerne, greb de studerende feedbacken forskelligt an. Nogle kommentarer havde blot form af venlig ros, mens andre var mere konkrete og retningsgivende. Ros har ifølge Hattie og Timperley (2007) ingen målbar positiv effekt på læring, så vi søgte at frembringe en kultur, hvor de studerende i højere grad forholdt sig konkret til det skrevne og opfordrede til mere konstruktiv og handlingsrettet feedback. Hattie (2014) har skrevet om selvtillid og ros, og at man skal være opmærksom på, hvordan disse elementer kan påvirke læreprocessen. Ros kan direkte modvirke præstationer, hvis den bliver drysset ud med rund hånd. Mens selvtillid, forstået som tillid til, at man selv har forudsætninger for at klare en specifik opgave, er vigtig for læringsudbyttet. Feedback er et vigtigt element af undervisning. Denne bør være informationsbaseret og fremadrettet for at være gavnligt for læring. Hattie skriver at:

"Feedback virker, fordi målet er kendt og præcist defineret gennem realistisk vurdering."

(Hattie 2014, s. 106)

De første tre gange modulet blev afholdt (E15, F16, E16), var der en tendens til, at der var lavt fremmøde til feedback-workshops i starten af modulet, og flere som modulet skred frem. Underviserne gav også løbende udtryk for, at deltagelse i feedback-workshops var yderst eksamensrelevant, da det netop var her, man som studerende kunne få afklaret sin forståelse for ugens tema. Fælles for alle forløb var, at godt halvdelen af de studerende valgte at deltage i feedback-workshops, dvs. deltage i det fysiske læringsrum. Flere valgte at arbejde med peer to peer feedback i det digitale rum.

En udfordring ved den digitale portfolio var, at flere studerende ikke oplevede, at de fik det fulde udbytte af peerfeedbacken og derved følte sig utrygge ved, om de havde opnået de forventede læringsmål, da de ikke selv var i stand til at vurdere dybden af deres egen viden. For at sikre en større sikkerhed blandt de studerende, og at de derved i løbet af modulet kunne opleve en større grad af succes og mindre grad af frustration, besluttede vi fra foråret 2016 at koble feedback-workshop og PBL-afslutning, så de lå i umiddelbart forlængelse af hinanden (se figur 5). De studerende fik derved mulighed for i højere grad at få "instant feedback" på deres portfoliobesvarelse under PBL-opsamlingen, hvor der også var en underviser tilstede, der kunne facilitere processen blandt de ti studerende, samt bidrage med retningsgivende feedback og præcisering 
af mål. I forbindelse med, at vi afviklede det nyudviklede modul for anden gang (F16), afprøvede vi også at være mere tydelig omkring de studerendes egne refleksioner over læring ved at bede dem om at gennemføre en selvevaluering af deres portfolioarbejde efter endt feedback ved at svare på nedenstående spørgsmål:

1. Var du i stand til at besvare alle opgaverne?

2. Hvilke hjælpemidler har du brugt i forhold til at svare på opgaverne?

3. Hvor lang tid har du brugt på at svare på opgaverne?

4. Vurderer du, at du efter at have svaret på opgaverne er i stand til at genfortælle dine svar til en medstuderende?

5. Vurderer du, at du efter at have svaret på opgaverne er i stand til at forklare få eller alle elementer af opgaverne?

6. Kan du forklare en medstuderende hvordan disse opgaver hænger sammen, og hvordan de er koblet til ugens situationsbeskrivelse og laboratorieaktiviteter?

Andet spørgsmål har til formål at bevidstgøre den studerende om anvendte kilder og derved åbne op for erfaringsudveksling af, hvordan man har anvendt fagbøger, ressourcer på internettet, videnskabelige artikler mv. Tredje spørgsmål giver anledning til refleksion over sammenhæng mellem arbejdsindsats og udbytte. Spørgsmål 4-6 er udarbejdet på baggrund af inspiration fra Biggs' SOLO taksonomi (figur 4). Svares der positivt på spørgsmål 4, befinder den studerende sig på niveauet uni-multistructural. Femte spørgsmål afdækker om den studerende er nået til niveaet relational i SOLO taksonomien, mens et positivt svar til det sidste spørgsmål indikerer, at den studerende har opnået dyb læring og befinder sig på at niveau, der nærmer sig extended abstract.

Efter at have læst en del portfoliobesvarelser igennem, er det undervisernes oplevelse, at besvarelserne samlet vidner om en dybere forståelse af de molekylærbiologiske problemfelter, end før den digitale portfolio og peer to peer feedback blev indført på modulet. Vi erfarede også, at de studerende arbejdede meget intenst på deres portfolioafleveringer og prioriterede dem højt, da de kunne se sammenhængen mellem afleveringer, laboratoriearbejde, projektarbejde og eksamen.

Af evalueringen for modulet i efteråret 2015 (E15) fremgik det, at de studerende havde brugt flere timer på deres studie og, at de var blevet bedre til selvstudie sammenlignet med evalueringen fra foråret 2015 (F15) (figur 8). På det gamle modul uden digital portfolio og peer to peer fedback (F15) svarede over halvdelen af de studerende, at de brugte mindre end 30 timer om ugen på studiet. På det nye modul (E15) var det kun en fjerdedel, der benyttede så lidt tid på studierne. Endvidere svarede kun en tredjedel af de studerende i F15 at: "Jeg ved, hvordan jeg skal gøre, når jeg studerer selv", mens over halvdelen af de studerende svarede positivt til dette spørgsmål i E15. Desuden fremgår det meget tydeligt, at andelen af studerende, der bruger mere end 40 timer om ugen på studiet er steget væsentligt fra portfolien blev indført i E15 frem til i dag, hvor det ved de seneste tre gange modulet har 
været afviklet, har givet et forholdsvis konstant højt niveau af studieintensitet (F16-F17).

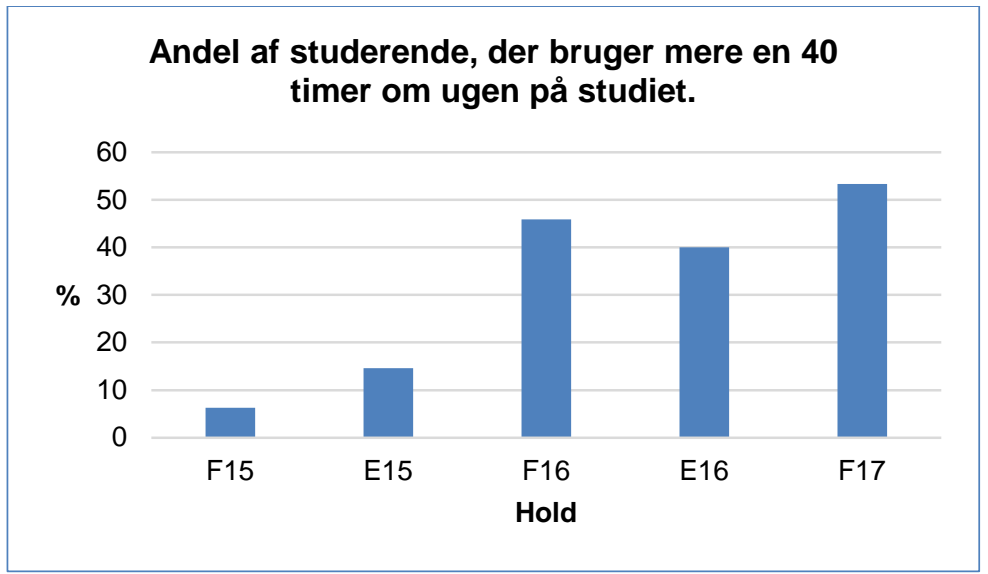

Figur 8. Studieintensitet. F15: Sidste årgang uden portfolio. E15: Første årgang med portfolio, løs ramme vedr. peerfeedback. F16-F17: Portfolio og peerfeedback som beskrevet ovenfor.

Over halvdelen af de studerende svarede i evalueringen efteråret 2015 (E15), at de var enige $i$, at havde fået tilstrækkelig feedback, så de selv kunne vurdere deres niveau, hvilket er en stigning i forhold til foråret 2015 (F15) før portfolien blev indført, hvor kun ca. en fjerdedel af de studerende oplevede, at de havde fået tilstrækkeligt feedback.

Samlet set kan vi se, at en større andel af de studerende bruger mere tid på studiet, efter vi har indført den digitale portfolio og peer to peer feedback, og der er sket en stigning i antallet af studerende der oplever, at de har fået tilstrækkelig feedback i løbet af modulet.

\section{Sammenligning af evalueringer fra moduler med og uden digital portfolio og peerfeedback}

Udvalgte elementer af modulevalueringer for årgangene bioe14 (M08 S16 og M09 E16) og biof15 (M08 V16 og M09 F17) er grafisk fremstillet i figur 9-12. M08 S16 og M09 E16 er samme årgang (56 studerende) på hhv. modul 8 og 9 i sommer og efterår 2016. M08 V16 og M09 F17 er samme årgang (44 studerende) på hhv. modul 8 og 9 i vinter 2016 og forår 2017. Begge moduler gennemføres som problembaseret læring, med den væsentlige forskel, at der anvendes digital portfolio og peer to peer feedback på modul 9. 


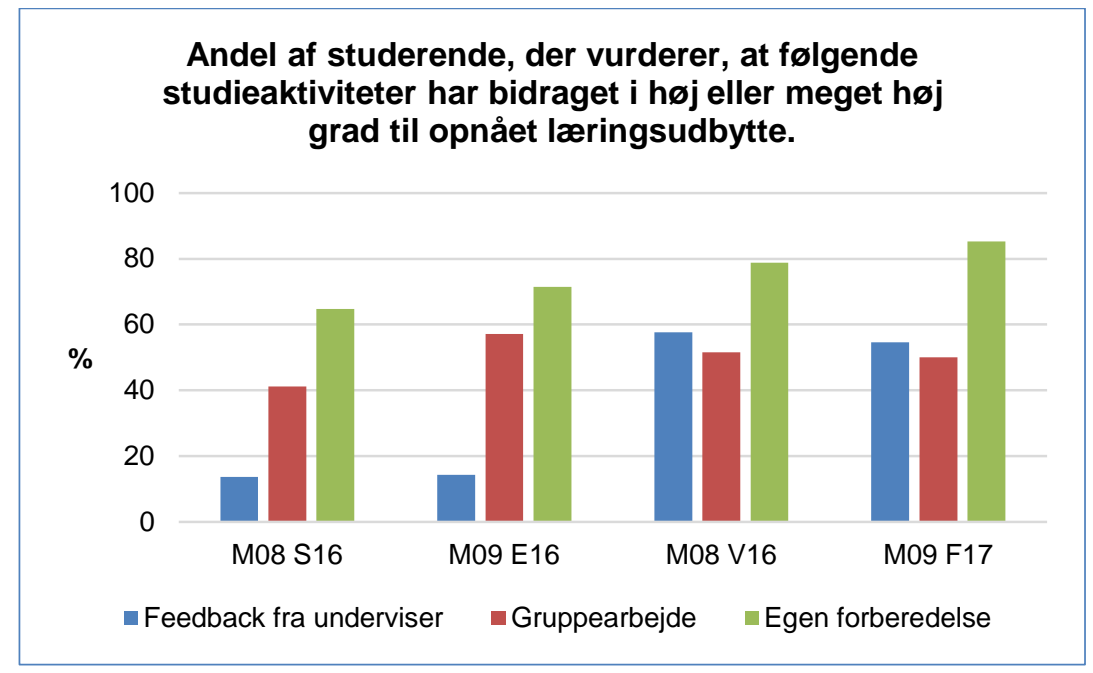

Figur 9. Studieaktiviteter der i høj eller meget høj grad bidrager til opnået læringsudbytte. M08 S16, M09 E16 er samme årgang og M08 V16, M09 F17 er samme årgang på hhv. modul 8 og 9.

Af figur 9 fremgår det, at de studerende opfatter feedback fra underviser, gruppearbejde og egen forberedelse som studieaktiviteter, der i samme grad bidrager til læringsudbyttet uanset hvilket modul, de har været på. Til gengæld ses der stor forskel mellem de to årgange (bioe14, biof15). Under 20 \% af de studerende på årgang bioe14 vurderer både på modul 8 og 9, at feedback fra underviser i høj eller meget høj grad bridrager til opnået læringsudbytte, mens over 50 \% af årgangen biof15 vurderer det samme.

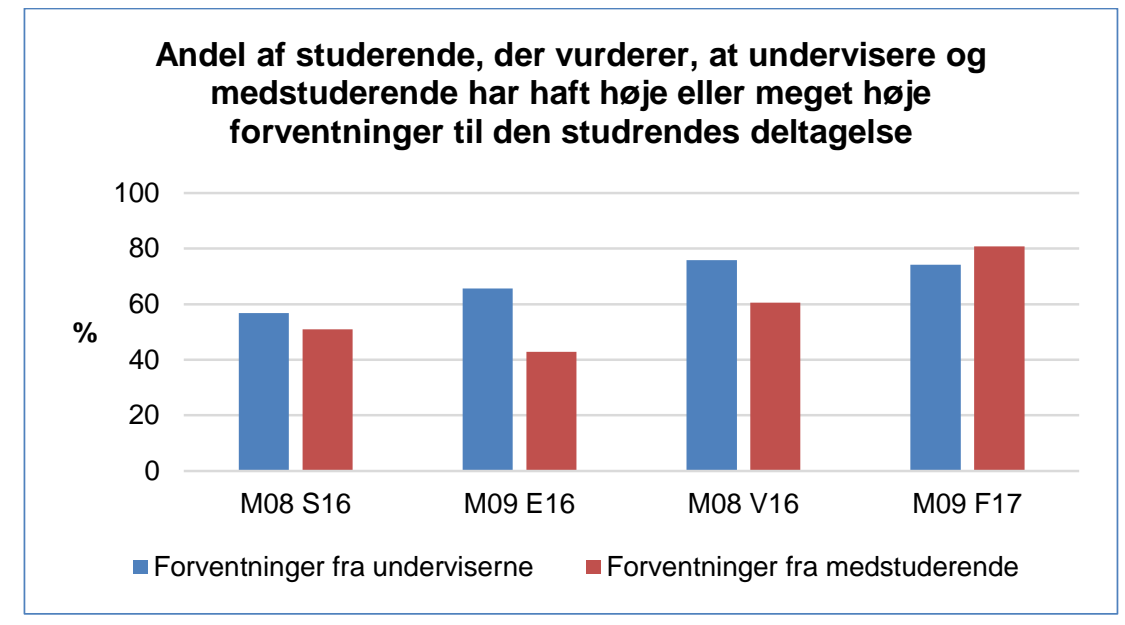

Figur 10. Forventninger til den studerendes deltagelse. M08 S16, M09 E16 er samme årgang og M08 V16, M09 F17 er samme årgang på hhv. modul 8 og 9.

Samme billede gør sig gældende for de studerendes vurdering af forventninger fra undervisere og medstuderende (figur 10). Mellem 42-66 \% af de studerende fra årgang bioe14 har vurderet, at forventningerne fra underviserne og medstuderende er høje eller meget høje, mens $61-81 \%$ af de studerende fra årgang biof15 vurdere det samme. 
En forskel på de to årgange er, at bioe14 er en større årgang med 56 Studerende, mens årgang biof15 er en mindre årgang med 44 studerende, hvilket muligvis kan have påvirket de studerendes opfattelse for mulighed for feedback fra medstuderende og undervisere, da der har været samme antal undervisere tilstede ved workshoptimer, laboratorieøvelser og anden undervisning uanset årgangens størrelse.

Anderledes ser billedet ud, når man sammenligner de studerendes opfattelse af de faglige krav og effekten af modulets studieaktiviteter. Som tidligere nævnt er en af de væsentligste forskelle mellem studieaktiviteterne på modul 8 og 9 arbejdet med den digitale portfolio og peer to peer feedback.

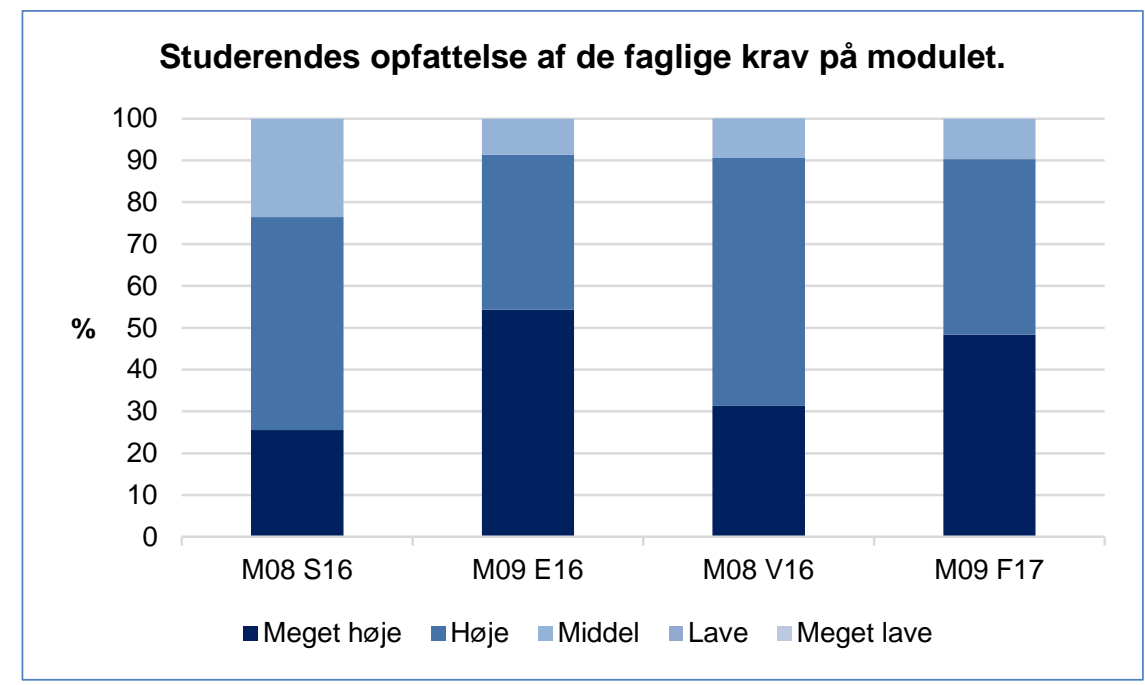

Figur 11. Procentvis fordeling af de studerendes opfattelse af de faglige krav på modulet.

Andelen af studerende, der opfatter, at de faglige krav på modulet er meget høje, er procentvis højere på modul 9 end på modul 8 (figur 11).

Tilsvarende ses det også, at andelen af studerende, der i meget høj grad oplever, at modulets studieaktiviteter har bidraget til, at de har følt sig faglig udfordret, at de er blevet udfordret til at gøre deres bedste, og har bidraget til, at de kan koble teori og praksis, er højere på modul 9 end på modul 8 (figur 12). 


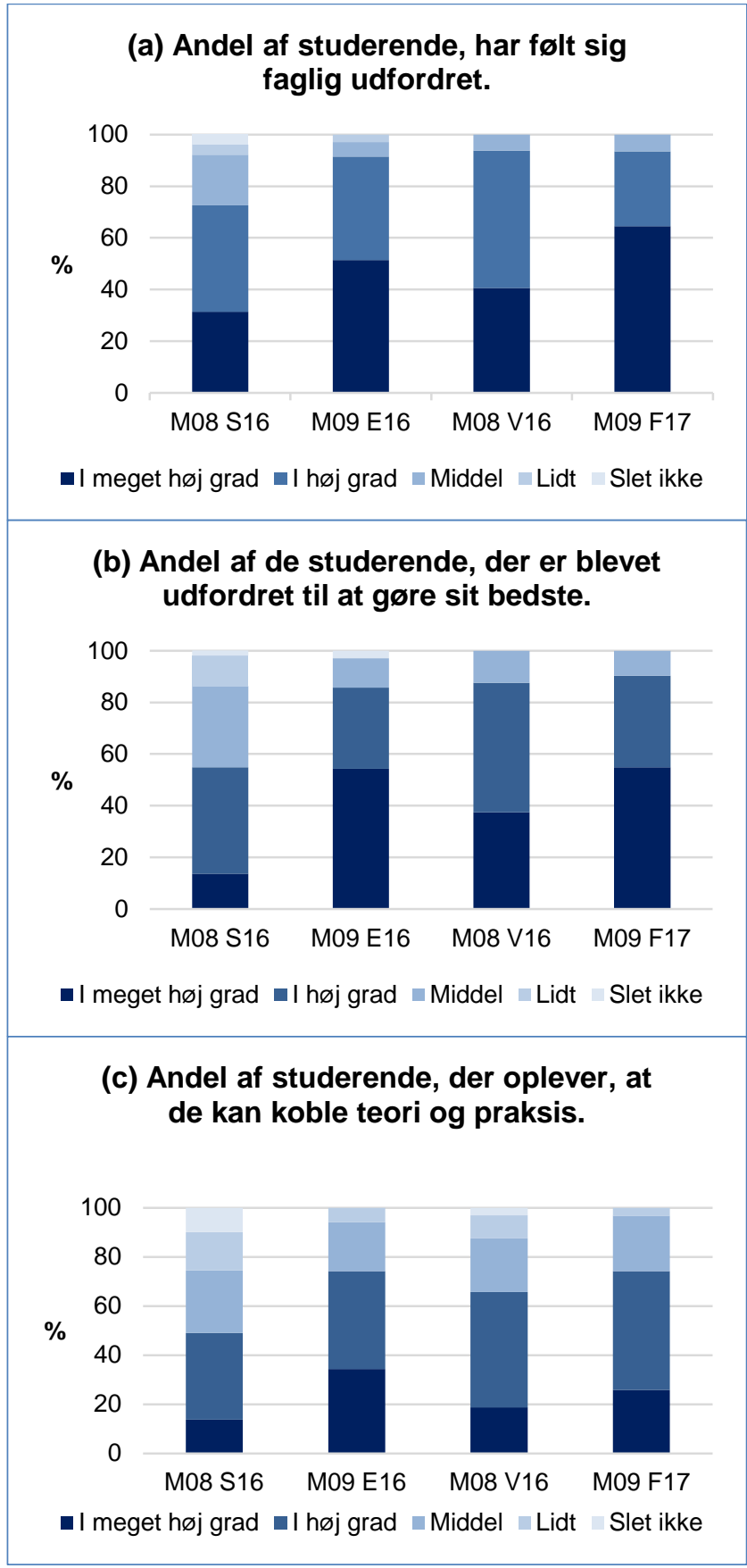

Figur 12. Procentvis fordeling af de studerende, der oplever, at modulets studieaktiviteter har bidraget til, (a) at de har følt sig faglig udfordret, (b) de er blevet udfordret til at gøre sit bedste og (c) de kan koble teori og praksis.

Samlet ser det ud til, at de studerende på modulet med portfolio og peerfeedback opfatter de faglige krav som højere, de føler sig mere fagligt udfordret og de kan i højere grad koble teori og praksis.

\section{Sammenhæng mellem karakter og tilstedeværelse ved feedback-workshop}

Ud fra indsamlede data viser der sig et billede af en sammenhæng mellem de studerendes tilstedeværelse ved feedback-workshop og den endelige eksamenskarakter. Af modulevalueringerne fremgår det, at der er flere studerende, der efterspørger mere feedback fra underviserne. Af figur 13 fremgår det, at der er en stor andel af de studerende, der ikke deltager i 
feedback-workshop og derved ikke benytter sig af muligheden for feedback fra underviserne, hvilket kan være en forklaring på, at de efterlyser mere feedback fra underviserne, på trods af, at de har muligheden for at dette en gang om ugen.

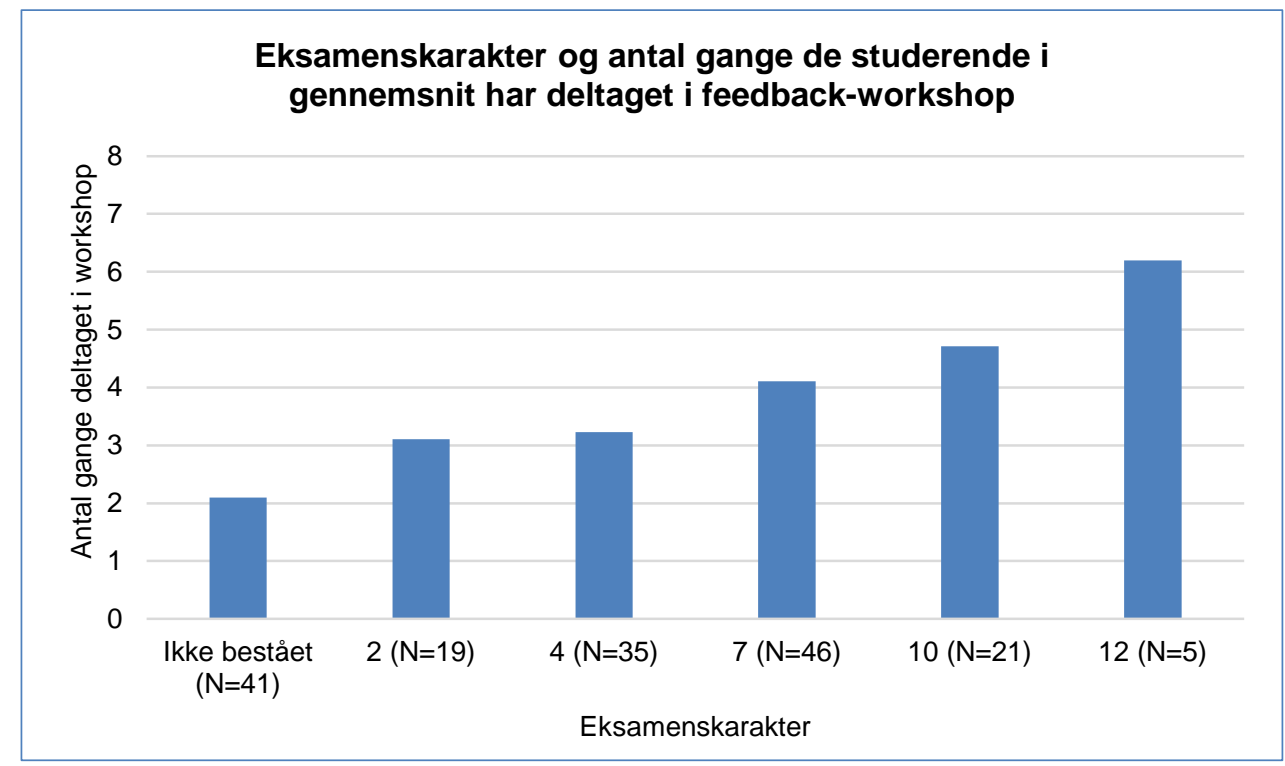

Figur 13. Deltagelse i feedback-workshop og eksamenskarakter. Der ses en sammenhæng mellem opnået eksamenskarakter og antallet af gange, de studerende i gennemsnit har deltaget i feedback-workshoppen. Data er baseret på alle studerende (N=167), der har gennemført undervisningsforløbet i F16, E16 og F17.

I forhold til arbejdet med den digitale portfolio fremgik det i F16 af evalueringens åbne besvarelser, at portfolien var den studieaktivitet, der især havde understøttet de studerendes læring på modulet. Det fremgik også, at de studerende har været glade for at vise deres portfolio til en anden studerende, da det har gjort, at de i højere grad har følt sig forpligtet til at aflevere en gennemarbejdet opgave. Nogle studerende efterlyser endnu tydeligere rammer for hvordan, de skal give feedback til hinanden. Dette opfatter vi som et udtryk for, at de studerende, der ikke har været til feedback-workshoppene, ikke altid har fået det fulde udbytte af feedbacken fra deres medstuderende.

Det efterlyses også af de studerende, at det kunne være godt med individuel feedback fra underviserne på portfolioafleveringerne. Dette har vi som undervisere vurderet var meget ressourcekrævende, og tilbyder i stedet den fælles feedback-workshop en gang om ugen, hvor der har været to undervisere tilstede, der har gennemgået de portfolioopgaver, som de studerende har haft behov for yderligere feedback på. Vi indsamlede i foråret og efteråret 2016 data for tilstedeværelse under hele modulet, og kunne derved konstatere, at det var lidt under halvdelen af de studerende, der valgte at møde op til de ugentlige feedback-workshops. Der var dog flere i slutningen af modulet end i starten. I foråret 2017 var fremmødet lidt over halvdelen, men det vurderes stadig, at der ligger et potentiale i at få flere studerende til at møde op til feedback-workshop således, at de i endnu højere grad oplever 
feedback på deres portfolioafleveringer. Indsamlede data viser da også en sammenhæng mellem tilstedeværelse ved feedback-workshops og eksamenskarakter (figur 13).

Der er en tendens til, at studerende, der får højere eksamenskarakter deltager i flere feedback-workshops end studerende med lave eksamenskarakter. Men man kan dog ikke sige noget om, hvorvidt et større fremmøde fører til en højere karakter, eller om det netop er gruppen af studerende, der får højere karakter, der vælger at deltage i feedback-worksops. Vi har dog oplevet en tendens til, at flere studerende med mindre udviklede studiekompetencer i løbet af modulet har hørt fra deres medstuderende, at der er et højt læringsudbytte forbundet med aktiv deltagelse i feedback-workshops, hvilket i sig selv har virket engagerende for denne gruppe. Workshoppen har givet mulighed for dialogisk kommunikation mellem studerende og undervisere og har dermed også virket udviklende på den faglige socialisering og professionsidentiteten (Dysthe \& Engelsen, 2005), hvilket igen kan være en drivkraft (Illeris, 2006) for de studerende.

\section{Sammenhæeng mellem portfolio og læringsudbytte}

Ser man nærmere på de åbne kvalitative besvarelser af evalueringerne fra modul 9 både i foråret og efteråret 2016 fremgår det tydeligt, at de studerende oplever det udbytterigt at arbejde med den digitale portfolio. I evalueringerne bliver de studerende bedt om at svare på følgende åbne spørgsmål: "Hvilke forhold i modulet har især understøttet din læring?" Ud fra de indkomne åbne besvarelser for modul 9 i efteråret 2017 svarer 78 \%, at portfolien især har understøttet deres læring. Nedenfor følger en række eksempler på besvarelser:

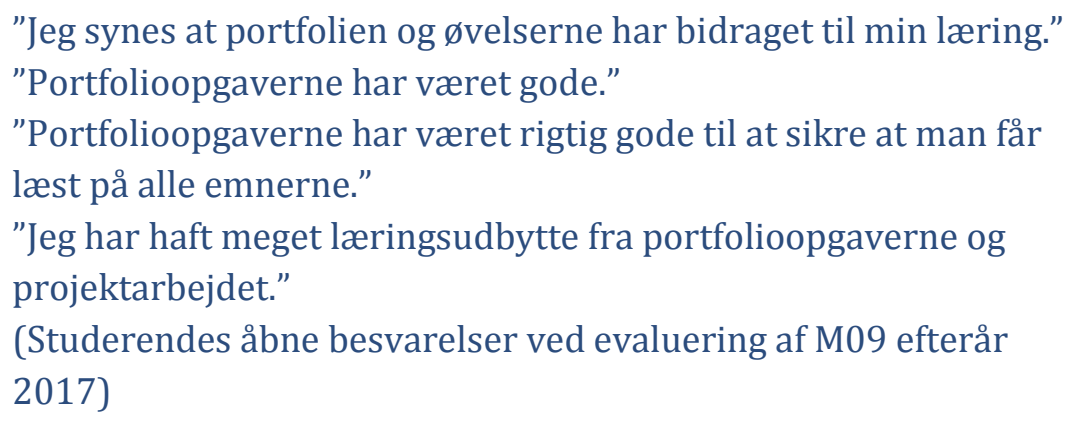

Desuden blev de studerende i evalueringen i efteråret 2016 også bedt om at svare kvantitativt på spørgsmålet: "I hvilken grad har portfolien bidraget til dit læringsudbytte?" Her svarer 91 \% i høj eller meget høj grad. Der er ingen tvivl om, at de studerende konsekvent er begejstrede for portfolien, men de vurderer ikke, at peer to peer feedback er tilstrækkeligt. De ønsker individuel feedback fra underviserne. Dette er på baggrund af de åbne besvarelser ved modulevalueringerne, som alle gange modulet har forløbet, viser samme billede. 
Det er tilsyneladende ikke ualmindeligt, at studerende og undervisere opfatter portoliens rolle forskelligt (Jæger \& Jensen, 2008). De studerende opfatter ofte en portfolio som et evalueringsredskab, mens undervisere opfatter det som et læringsredskab. Derfor er det også særligt vigtig at underviserne er meget eksplicitte i forhold til formålet med portfolio og feedback og gentagne gange i løbet af undervisningsforløbet er i dialog med de studerende om forventninger til læring og og læringsudbytte.

\section{Anbefalinger og opmærksomhedspunkter i forhold til digital portfolio og peer to peer feedback}

På baggrund af de erfaringer vi har gjort os med hensyn til udvikling, implementering og evaluering af digital portfolio og peer to peer feedback er der følgende fokuspunkter, vi vil anbefale, at man er opmærksom på:

Introduktionen og den første vejledning i anvendelse af digital portfolio og peer to peer feedback er vigtig i forhold til at få hele årgangen med i det digitale rum fra starten af modulet.

Hvis de studerende ikke har erfaring fra tidligere $\mathrm{i}$ at give og modtage feedback, skal denne proces understøttes med tydelige rammer både for afsender og modtager af feedback.

I forhold til rammesætning af feedback er det vigtigt at fokusere på konkret handlingsrettet feedback, så den der modtager feedbacken, kan udvikle sit arbejde yderligere.

Rammen for det fysiske feedbackrum er lige så vigtig som rammen for det digitale feedbackrum. Der skal aftales spilleregler i begge rum.

Hvis man vælger at indføre digital portfolio og peerfeedback, kan der muligvis opstå frustrationer blandt de studerende første gang, man kører forløbet igennem. Løbende justeringer og kollegial sparring er betydende for en fremadrettet og udbytterig proces.

Man skal være opmærksom på, at der kan være forskel på forskellige årgange, så igen er det vigtigt som underviser at være lydhør over for de studerende og løbende justere faciliteringen af den digitale portfolio og peerfeedback.

Som konsekvens af de kontinuerlige tilbagemeldinger vedrørende ønske om individuel feedback, har vi overvejet, om vi skal tilbyde individuel feedback på en mindre præsentationsportfolio, som de studerende sammensætter ud fra en af deres refleksionportfolier. Dette koster undervisningstimer, som i givet fald, skal skæres fra tiden sammen med de studerende. En udvikling af modulet kunne også være, at vi kunne udvikle en afkrydsnings peerfeedback model, så de kan give hinanden en vurdering på udvalgte emner. Vi kunne evt. prøve dette på en enkelt portfolioopgave, eller delelementer af flere af opgaver. Denne mulighed er netop blevet udviklet som en integreret del af 
Metropols Learning Management System, og kunne være interessant at afprøve i kombination med den eksisterende peer to peer feedback model.

På modul 8 er de studerende glade for quizzer koblet til Learning Management System i forbindelse med PBL-afslutning. Man kunne overveje at understøtte forløbene på modul 9 med selvtest-quizzer. Det kunne muligvis bidrage til at give de studerende en følelse af, at de fik en vurdering af deres faglige niveau undervejs.

Ved den seneste evaluering i F17 foreslog de studerende, at der skrives flere nøgleord ind i portfolioopgaverne, som skal anvendes i besvarelsen. Dette kunne også være en mulighed for at kvalificere hvilke fagtermer, det forventes, at de anvender i deres portfolio, da det kan hjælpe de studerende, som netop ikke har så veludviklet et fagsprog, til at øve sig i at benytte de rette fagudtryk i rette sammenhæng.

\section{Konklusion}

Portfolioopgaverne understøtter i høj grad de studerende i deres læring. De bliver gode til at studere selv, de studerer i flere timer, de bliver fagligt udfordret, og de bliver bedre til at koble teori med praksis. Som udfordring angiver de studerende på alle de forløb, vi indtil nu har gennemført, at de $\emptyset$ nsker mere individuel feedback fra underviser. Vi har derfor stadig en udfordring som undervisere i forhold til at tydeliggøre, at aktiviteterne, der finder sted til feedback-workshop, også er feedback fra undervisere.

Udvikling, implementering og evaluering af digital portfolio og peer to peerfeedback har foruden at styrke de studerendes faglighed og studiekompetencer også bidraget til kompetenceudvikling af underviserne, der har været involverede. Det har været en lærerig proces, som i høj grad fordrer, at vi som undervisere udfordrer os selv igen og fortsætter med at udvikle nye didaktiske tiltag til styrkelse af de studerendes læring.

\section{Referencer}

Andre, Dr. K. \& Heartfield, Dr. M. (2007). Professional Portfolios Evidence of Competency for Nurses and Midwifes. Elsevier Australia.

Barrett, H. C. (2011). Balancing the Two Faces of ePortfolios, British Columbia Ministry of Education, Innovations in Education, 2nd Edition. Retrieved April 27, 2017 from http://electronicportfolios.org/balance/Balancing2.htm.

Biggs, J. \& Tang. C. (2007). Teaching for Quality Learning at University. 3. udg. Open University Press.

Cook-Sather, A., Bovill, C. \& Felten P. (2014). Engaging Students as Partners in Learning and Teaching - A Guide for Faculty. Jossey-Bass A Wiley Brand, United States of America. 
Danske professionshøjskoler (2016). Feedback i undervisningen på professionshøjskolerne, Idékatalog om feedback udarbejdet af de studerendes faglige organisationer, (LL, SLS, SDS og PLS) Dansk Magisterforening, Dansk Sygeplejeråd og Danske Professionshøjskoler. Retrieved April 27, 2017 from http://danskeprofessionshøjskoler.dk/wpcontent/uploads/2017/04/Feedback-i-undervisningen 2017 V7.pdf.

Dysthe, O. \& Engelsen, K. S. (red.) (2005). Mapper som pædagogisk redskab. Forlaget Klim.

Hattie, J. \& Timperley, H. (2007). The Power of Feedback, Review of Educational Research. 77, 81-112, DOI: 10.3102/003465430298487.

Hattie, J. \& Yates, G. C. R (2014). Synlig læring og læringens anatomi. Dafolo.

Illeris, K. (2006). Læring. Roskilde Universitetsforlag.

Jæger, K. \& Jensen, A. A. (2008). Et organisatorisk perspektiv på portfolio, Lund, B. (red.) Portfolio i et lærings og uddannelsesperspektiv. Aalborg Universitetsforlag.

Lorenzen, H. \& Thomasen, I. N. (2017). Facilitering af selvstudiet i problembaseret læring - et læringsdesign for asynkron kommunikation, Læring \& Medier, 16.

Lund, B. (2008). Læringsteoretiske begrundelser for portfolien som pædagogisk redskab i en skandinavisk tradition, Lund, B. (red.) Portfolio $i$ et lærings og uddannelsesperspektiv. Aalborg Universitetsforlag.

Mezirow, J. (2012). Hvordan kritisk refleksion fører til transformativ læring. Illeris, K. (red.) 49 tekster om læring. Samfundslitteratur.

Nielsen, P. B. \& Månsson, C. (2011). Transfer -hvilke faktorer sikrer hensigtsmæssig overførsel og anvendelse af viden, Danske Bioanalytikere. 11, 24-28.

Professionshøjskolen Metropol (2014). Strategi 2020, Retrieved May 5, 2017 from https://www.phmetropol.dk/om+metropol/strategier.

Studieordning for Professionsbachelor i Biomedicinsk Laboratorieanalyse (2009). Retrieved June 2017 from https://www.phmetropol.dk/uddannelser/bioanalytiker/uddannelsen/stu dieordning. 